\title{
A Gravity Model of Net Benefits of EU Membership : The Case of Ukraine
}

\author{
Oleksandr Shepotylo \\ Kyiv School of Economics
}

\begin{abstract}
This paper develops a methodology for trade policy analysis of costs and benefits of alternative regional integration scenarios. The methodology is based on the disaggregated gravity equation, which is applied to calculate the impact of the EU enlargement on integration strategies of non-member countries. In particular, the paper measures the impact of the 2004 EU enlargement from the standpoint of Ukraine - a country that has been lost in transition. This angle allows estimating the costs of non-integration that occurred due to trade and investment diversion, and forgone opportunity to carry out structural changes in the Ukrainian economy. According to the results, the EU accession would have had a positive effect on total export volumes and would have changed the composition of Ukrainian exports by almost doubling exports of manufactured goods by 2007. The costs of non-integration accumulate towards the end of the investigated period. Projecting the results into the future clearly indicates that the benefits of the EU accession for Ukraine would have been unambiguously positive and would overweight benefits of the CIS integration.
\end{abstract}

- JEL Classification: C33, F12, F17, P33

- Keywords: Gravity Model, EU Enlargement, Ukraine, CIS, Heterogeneous Firms, Trade Policy

\footnotetext{
*Corresponding address: Oleksandr Shepotylo, Kyiv School of Economics, Yakira, 13, Suite 332, 04119 Kyiv, Ukraine; Tel.: (38-044) 492-80-12, Fax: (38-044) 492-80-11; oshepotylo@eerc.kiev.ua. (2010-Center for Economic Integration, Sejong Institution, Sejong University, All Rights Reserved.
} 


\section{Introduction}

What are the costs and benefits of joining a regional free trade agreement (FTA)? Which FTA would be more beneficial for a country that has to choose among several alternative integration strategies? The studies of European Union (EU) enlargement give us a partial answer to these questions by focusing on the impact of the enlargement on the current and new EU members. ${ }^{1}$ However, the literature says little about either what would have happened to the new EU members under some alternative integration scenarios or what would have happened to non-members if they had integrated into the EU.

This paper takes a step forward in this direction and develops a gravity model based methodology for evaluating alternative regional integration scenarios in terms of volume and composition of exports. The paper further applies the methodology to estimate costs of non-integration into the EU for non-member countries and to compare them with costs under alternative integration scenarios. To be more specific, the paper focuses on Ukraine as a good example of a country that still has to decide on which integration strategy - the EU or the Russian centered - would be more beneficial in terms of the volume and composition of its exports. $^{2}$

The offered method assumes that the main differences between being an EU member and being a Commonwealth of Independent States (CIS) member stem from the changes in behavioral relationships of the parameters of the gravity equation rather than from the changes in factors that represent the gravity forces (see Egger, Pfaffermayr, and Schmidt, 2006). In addition to evaluating the behavioral change, the novelty of the paper lies in applying an estimation of the disaggregated gravity equation using the two stage procedure developed by Helpman, Melitz, and Rubinstein (2008) (henceforth HMR). The method explicitly deals with a substantial number of zero trade flows and unobserved firm-level heterogeneity which are present in the data. Unlike the HMR method, we exploit both cross-sectional and time dimensions to remove the pair-specific fixed effects that can bias the cross-sectional results and estimate the impact of the EU accession

\footnotetext{
${ }^{1}$ See, for example, Baldwin (1995), Gros and Gonciarz (1996), Brenton and Di Mauro (1998), Nilsson (2000), Bussiere et al. (2008).

${ }^{2}$ Export to GDP ratio of Ukraine in 2007 was $40 \%$. At the same time the composition of exports was poorly diversified and skewed towards exports of raw materials and primary commodities. The main item of exports is basic metals which accounted for $42 \%$ of all exports in 2007 .
} 
on bilateral trade flows by the Hausman-Taylor method (Hausman and Taylor, 1981) treating the EU accession as an endogenous decision that correlates with variable and fixed costs of trade.

The model demonstrates that Ukraine would benefit both from regional integration with the CIS or from regional integration with EU countries, however, the benefits are higher under the EU integration strategy. The benefits of the EU integration relative to the CIS integration are twofold. Higher aggregate trade is one of them - the EU integration would have increased exports in 2004-2007 by $10 \%$, while the deeper CIS integration would have increased exports by $4 \%$; but, more importantly, higher export diversification under the EU integration scenario would reduce risks of idiosyncratic terms of trade shocks and increase probability of the higher economic growth in the future (see Hausmann, Hwang, and Rodrik, 2007). The higher export diversification is achieved because of the rapid expansion of manufactured exports - the share of manufactured goods would have been $26 \%$ under the EU scenario and only $16 \%$ under the CIS scenario- and consequent reduction of the share of raw and processed materials in total exports.

The structure of the paper is as follows. Section II compares existing trade patterns of the Eastern European countries with trade patterns of the CIS countries. Section III briefly discusses the methodological issues, presents a theoretical model and develops the estimation procedure. Section IV discusses data. Section V presents estimation results for aggregated trade data and discusses advantages of the Hausman-Taylor method. It also presents estimated gains in disaggregated exports from the EU-Ukraine trade integration for two counterfactual experiments. Finally, Section VI concludes.

\section{Behavioral Differences between the EU and CIS Countries}

\section{A. First Glance at the Data}

The theory of regionalism and preferential trade agreements (i.e. Baldwin, 1993; Baldwin et al. 2006) stresses that costs of non-integration into a regional trade bloc increase with the size of the bloc which, in turn, induces more countries to join the bloc due to a so-called "domino effect": by lowering trade barriers and improving market access, a discriminatory liberalization of trade within a trading bloc gives an edge to the companies located within the bloc over the outsiders and create 
incentives for multinational companies (MNC) to move their activities inside. ${ }^{3}$ This creates an additional pressure for inclusion on outside countries. Hence, once started, the process of regionalization captures ever-growing number of countries.

The story of the latest EU enlargement illustrates this point. The Council of Mutual Economic Assistance (CMEA) that, by 1989, included fifteen Soviet republics, six Eastern European countries - Bulgaria, Czechoslovakia, East Germany, Hungary, Romania, Poland -, and three other countries - Cuba, Mongolia, and Vietnam generated a substantial intra-bloc trade due to a high degree of economic and political integration. ${ }^{4}$ As pointed out by Beckmann and Fidrmuc (2009), CMEA was politically motivated and somewhat artificial, plagued with price controls and manipulation of energy prices for political ends. Its distinct features were the hub-and-spoke structure with the USSR dominating export of raw materials to other CMEA countries and compensating import of manufactured goods to the USSR from the other members, much lower trade integration of small CMEA members with each other, and reliance on autarky economic model to protect against external shocks. Actual trade of Eastern and Central European members of CMEA with Northern Europe was 50\% below potential - difference of 53 billion dollars in 80-82 (Havrylyshyn and Pritchett 1991).

Since the beginning of transition, Eastern European countries and Baltic States have rapidly moved away from the Moscow-centered economic gravity. As was correctly predicted by some scholars (i.e. Wang and Winters, 1991 Hamilton and Winters, 1992, and Baldwin, 1994), this led to the reorientation of their trade flows away from the CMEA countries towards the EU members. By 1995, Eastern European trade flows did not differ considerably from that of similar Western European countries and mostly exhausted the westward expansion of exports at the intensive margins of trade (Gros and Gonciarz (1996). This view is supported by a more recent World Bank (2005) report which shows that currently most of the EU12 countries trade above their potential level.

The accession of twelve Eastern European countries (EU12) into the EU in 2004 and 2007 finalized the process of integration. It further reduced trade barriers within the EU, mostly between EU12 countries themselves rather than between

${ }^{3}$ In EFTA nations, the possibility of investment diversion was an important factor in the policy debates on EC membership: Baldwin et al. (1992) showed outflows of investments from EFTA countries due to the EEC enlargement.

${ }^{4}$ Pelzman (1977) has found that the integration of the socialist countries into CMEA has generated a substantial additional intra-bloc trade at the expense of the trade with the rest of the world. He estimated the value of trade creation effect at 13.2 billion of \$US in 1970 . 
EU12 and the old EU members, and made the EU12 countries even more attractive destinations of FDI due to a favorable investment climate and convenient central location for serving nearby markets. The 12 former Soviet Union republics (excluding Baltic States), on the other hand, have chosen to create an economic and political union, known as the Commonwealth of Independent States. Its formation was finalized in 1994 when the CIS Charter was ratified by 10 CIS members, except Turkmenistan and Ukraine which have chosen to participate in CIS selectively as associated members. However, the eastward expansion of EU and rapid economic growth of East Asia considerable weakened the economic attractiveness of CIS. In August 2009, Georgia officially denounced its membership in the CIS, while Ukraine and several Central Asia countries were actively seeking closer economic relationships with the EU and China consequently.

Figure 1 reports exports from EU12 and CIS countries in five broad product categories as well as total exports. It reveals a spectacular expansion of exports of

Figure 1. Exports of EU12 and CIS in 2000-2007

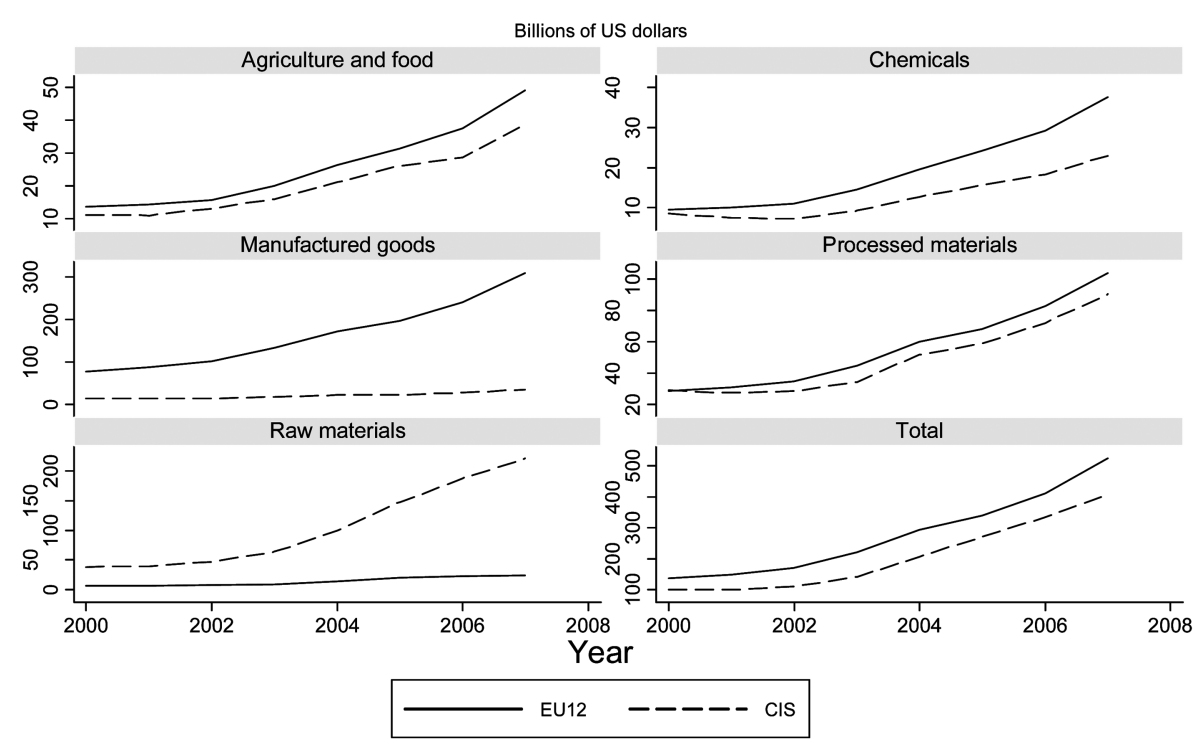

Source: COMTRADE, 2000-2007

EU12 - new EU members in 2004-2007, CIS - commonwealth of independent states. SITC2 exports at 1 digit level are aggregated into five groups:Agriculture and Food - SITC 1 digit codes 0,1, and 2; Raw materials - codes 3 and 4; Chemicals - code 5 Processed materials - code 6 Manufactured goods - codes 7 and 8. 
manufactured goods ${ }^{5}$ from the EU12 countries that exceeded 300 billion US dollars by 2007. The driving force of the CIS export growth, on the other hand, was the expansion of exports of raw materials that grew well over 200 billion dollars by 2007. At the same time, exports of manufactured goods from the CIS stagnated.

One of the explanations of the stark differences between EU12 and CIS in terms of industrial composition of exports is that an intra-industry and intra-firm trade increased significantly in EU12 between 2000 and 2007. By attracting MNCs for locating their plants, EU12 has substantially increased intra-industry trade in high value added products and became an export platform for serving the CIS markets, while CIS countries failed to integrate into the global chains of production: the share of intermediate exports in the total export reached $20 \%$ in EU $8^{6}$ and only $6 \%$ in CIS. ${ }^{7}$

\section{B. Regional Integration Strategies for Ukraine}

De facto, Ukraine is a member of the CIS. However, Ukraine participates in the CIS programs very selectively and the Ukrainian parliament never ratified the CIS Charter. Moreover, after 2004, Ukraine explicitly declared the EU accession as its strategic goal and further reduced cooperation with the CIS. Ukraine is an eligible candidate for the EU enlargement based on the geographical criteria. It is an important EU trading partner that moves towards EU both politically and economically. In February, 2008, the Ukraine has started a round of free trade agreement (FTA) negotiations with EU which is the next step towards the EU integration. The launch of negotiations followed the finalization of Ukraine's WTO accession process on February, $52008,{ }^{8}$ which was a prerequisite for FTA talks.

Therefore, the advantages of looking at Ukraine while comparing costs and benefits of a deeper EU integration vs. deeper CIS integration are as follows. First, it is not a purely theoretical exercise but a question of practical importance. Did Ukraine make a right choice when declaring the EU integration as the policy priority? Second, the answer to this question gives guidance for policymakers of the EU and Ukraine for the decision on the future of the EU enlargement process.

\footnotetext{
${ }^{5}$ Products 7 and 8 of SITC classification at one digit level of aggregation.

${ }^{6}$ EU8: Eastern European countries that joined EU in 2004 not including Cyprus and Malta.

${ }^{7}$ Pradeep Mitra, "Innovation, Inclusion and Integration", World Bank 2008.

${ }^{8}$ Ukraine submitted the application on November 20, 1993. On 5 February, 2008 it has been announced that Ukraine would become a member of the World Trade Organization (WTO) on June 4, 2008 after almost 15 years of negotiations.
} 
Suppose that, contrary to the fact, the Ukraine joined EU in 2004. The accession conditions would require the Ukraine to satisfy a list of certain criteria that include stable democratic institutions, respect for the rule of law, a functioning market economy, and an adjustment of the administrative structure. The deep political, economic and administrative reforms coupled with better access to the large EU market and proximity of the CIS markets would lead to a significant improvement of investment climate and a consequent behavioral change in the Ukrainian economy, its industrial structure, and composition of export.

\section{Model and Estimation Methodology}

\section{A. Estimation of the Gravity Model: Econometric Issues}

Due to prevalence of zero trade flows (an average share of non-zero trade flows across industries at SITC two-digit level is $22 \%$ ) and importance of distribution of firms within an industry for evaluation of changes in trade policy (e.g. Melitz, 2003; Bernard et al., 2003), the traditional one-stage procedures of estimating the gravity model produce biased estimates. Ignoring zeroes in the bilateral trading matrix leads to the bias in the estimation of the gravity equation due to correlation between fixed costs of exporting and volumes of trade. Ignoring the heterogeneity of firms while evaluating potential gains from integration of the Ukraine into EU would miss the gains stemming from increasing productivity and restructuring of the product composition of exports. To mitigate the problems, we suggest a modified version of the HMR model that takes into account zero trade flows and heterogeneity of firms.

\section{B. Model of Bilateral Export}

We modify the HMR set up by adding sectors indexed $k=1, \ldots, K$. Each country $i=1 \ldots C$ has $N_{k}^{i}$ firms that produce differentiated products in sector $k$. A country $i$ firm produces one unit of output with $w^{i} a$ units of labor. ${ }^{9} w^{i}$ is country specific, reflecting the differences in institutions, technology, and factor prices. Each firm is a monopolist over the production of a distinct good, but is small relative to the size of the market. Following Melitz (2003), we specify $a$ as a firm-specific parameter with the cumulative distribution function $G_{k}(a)$ over support $\left[a_{k \min }, a_{k \max }\right]$. There

${ }^{9}$ We consider a partial equilibrium model with fixed capital during the period being investigated. Labor is the only input that is perfectly mobile across industries, but immobile across countries. 
are variable and fixed costs of delivering products to consumer markets, indexed $j$, that vary across industries. $T_{k}^{i j}$ is a melting iceberg transportation cost with $F_{k}^{i j}>0, F_{k}^{i i}=0$. is a fixed cost of exporting that is country-pair and industry specific with .

The profit of the firm exporting to country $j$ is:

$$
\pi_{k}^{i j}(a)=\frac{\theta_{k}}{\sigma}\left[\frac{\sigma T_{k}^{i j} w^{i} a}{(\sigma-1) P_{k}^{j}}\right]^{1-\sigma} Y^{j}-F_{k}^{i j}
$$

where $\sigma>1$ is the elasticity of substitution across different products, $\theta_{k}$ is the expenditure share of industry $k$ in total consumption, $P_{k}^{j}$ is the price index in industry $k, Y^{i}$ is the total expenditures in country $j$.

The firm exports only if it receives positive operating profits. The least productive firm that exports to country $j$ has the productivity level $1 / a_{k}^{i j}$ determined as:

$$
\pi_{k}^{i j}\left(a_{k}^{i j}\right)=0 \Leftrightarrow \frac{\theta_{k}}{\sigma}\left[\frac{\sigma T_{k}^{i j} w^{i} a_{k}^{i j}}{(\sigma-1) P_{k}^{j}}\right]^{1-\sigma} Y^{j}=F_{k}^{i j}
$$

Out of $N_{k}^{i}$ firms that operate in country $i$ in industry $k$, only $N_{k}^{i} G_{k}\left(a_{k}^{i j}\right)$ firms export to country $j$. The aggregate export in industry $k$ from exporter $i$ to country $j$ is:

$$
\begin{aligned}
& X_{k}^{i j}=N_{k}^{i} G_{k}\left(a_{k}^{i j}\right) E\left(p_{k}^{i j}(a) c_{k}^{i j}(a) \mid \pi_{k}^{i j}(a)>0\right)=N_{k}^{i} \theta_{k} Y^{j} V_{k}^{i j}\left(\frac{\sigma T_{k}^{i j} w^{i}}{(\sigma-1) P_{k}^{j}}\right)^{1-\sigma} \text { if } \\
& a_{k}^{i j}>a_{k \text { min }} \text { and } X_{k}^{i j}=0 \text { otherwise, where } V_{k}^{i j}=\int_{a_{k \min }}^{a_{k}^{i j}} a^{1-\sigma} d G_{k}(a) .
\end{aligned}
$$

The equation can be further simplified by using the equilibrium constraint on the output of sector k produced by country i which leads to the following export equation:

$$
X_{k}^{i j}=s_{k}^{i} Y^{i} Y^{j} V_{k}^{i j} \frac{\left(\frac{T^{i j}}{P_{k}^{j}}\right)^{1-\sigma}}{\sum_{j=1}^{C}\left(\frac{T_{k}^{i j}}{P_{k}^{j}}\right)^{1-\sigma} Y^{j} V_{k}^{i j}} \text { if } a_{k}^{i j}>a_{k \min } \text { and } X_{k}^{i j}=0 \text { otherwise }
$$

\section{Parameterization and Estimation}

Substituting for $\left(T_{t}^{i j}\right)^{\sigma-1}=\left(d i s t^{i j}\right)^{\rho} \exp \left(Z \gamma-u_{t}^{i j}\right)$ and taking the logs of both 
sides of equation (3), where dist $t^{i j}$ is the distance between countries $i$ and $j, Z$ is a set of additional variables that determine trade costs, $\gamma$ is the vector of coefficients associated with $Z$, and $u_{t}^{i j}$ is the error term, yields:

$\ln \quad X_{t}^{i j}=\ln s^{i}+\ln Y_{t}^{i}+\ln Y_{t}^{j}-\rho \ln d i s t^{i j}-Z \gamma-(1-\sigma) \ln P_{t}^{j}-\ln M R T_{t}^{i}+\ln V_{t}^{i j}+u_{t}^{i j}$

where $\ln M R T_{t}^{i}=\ln \left(\sum_{j=1}^{C}\left(\frac{T_{t}^{i j}}{P_{t}^{j}}\right)^{1-\sigma} Y_{t}^{j} V_{t}^{i j}\right)$ is the multilateral resistance term, an integral measure of trade barriers of a country vis-à-vis all its trading partners (Anderson and van Wincoop, 2003). ${ }^{10}$

There are two problems that do not allow estimating equation (4) directly. First, the multilateral resistance term, $\ln M R T_{t}^{i}$, and price level, $\ln P_{t}^{j}$, are not observable, and according to theory is simultaneously determined for all countries. A traditional approach to deal with the multilateral resistance term and unobserved price level is by introducing country fixed effects (see Baldwin and Taglioni, 2006, for a discussion on the usage of fixed effects in the gravity equation).

Second, even controlling for the multilateral resistance and prices, $E\left(\ln V_{t}^{i j}+u_{t}^{i j} \mid X_{t}^{i j}>0\right) \neq 0$. Following HMR, we deal with this issue by introducing a two-stage Heckman procedure, estimating determinants of selection into exporters and non-exporters and degree of industry-level heterogeneity at the first stage, before estimating the gravity equation at the second stage. In particular, HMR showed that $E\left(\ln V_{t}^{i j}+u_{t}^{i j} \mid X_{t}^{i j}>0\right)=b_{0} \hat{\eta}_{t}^{i j}+\sum_{m=1}^{3} b_{m}\left(\hat{\psi}_{t}^{i j}\right)^{m}$, where $\hat{\delta}_{t}^{i j}$ is the predicted probability of positive exports, $\hat{\eta}_{t}^{i j}$ is the traditional inverse Mills ratio that accounts for the sample selection bias and the polynomial of degree three in $\hat{\psi}_{t}^{i j}=\hat{\eta}_{t}^{i j}+\Phi^{-1}\left(\hat{\delta}_{t}^{i j}\right)$, where $\Phi($.$) is normal cdf, corrects for the firm level$ heterogeneity. We do not assume any specific functional form for distribution of productivity. As shown by HMR, the polynomial of degree 3 is a sufficiently flexible and accurate approximation of the underlying unknown distribution of productivities, $G(a)$.

The baseline model specification takes the following form:

$$
\ln X_{t}^{i j}=\ln s_{i}+\ln Y_{t}^{j}+\ln Y_{t}^{j}+b_{0} \hat{\eta}_{t}^{i j}+\sum_{m=1}^{3} b_{m}\left(\hat{\psi}_{t}^{i j}\right)^{m}-\rho \ln \operatorname{dis} t^{i j}-Z \gamma+\omega_{t}^{i j}, \mathrm{t}=1,2 \ldots T
$$

\footnotetext{
${ }^{10}$ We drop industry index $\mathrm{k}$ to simplify notation.
} 
where $\omega_{t}^{i j}=-(1-\sigma) P_{t}^{j}-\ln M R T_{t}^{i}+u_{t}^{i j}$. In this specification, we have exporter and importer fixed effects, common time effect, and pair specific component, $\omega_{t}^{i j}$, that is random and independently distributed across country-pairs. We also allow for the correlation between $\omega_{t}^{i j}$ and the components of vector $\mathrm{Z}$ that are related to the integration decisions. In particular, we treat an EU accession decision as an endogenous variable because it is linked to the graphical location of a country that correlates with the bilateral trade costs. For example, Baier and Bergstrand (2004) demonstrates that joining an FTA is more likely to be positive for countries that are closer, for pair of countries that are remote, for countries that are bigger and similar in the level of economic development.

We apply the Hausman-Taylor method which uses time-varying variables that are not correlated with $\omega_{t}^{i j}$ as instruments for endogenous components of $Z$. Serlenga and Shin (2007) tested performance of the Hausman-Taylor method in estimating the gravity equation of bilateral trade flows among 15 European countries in 1960-2001 and found that it provides more sensible results than fixed or random effect methods. McPherson and Trumbull (2008) used the HausmanTaylor method to estimate the unrealized US-Cuban trade potential and also found it superior to other popular methods of estimating the gravity model on panel data.

\section{Data Sources and Variable Definitions}

To capture the behavioral differences between the CIS countries and EU12 countries, we separately estimate the gravity model for the EU sample (exports from twelve EU member countries that recently joined EU (EU12) ${ }^{11}$ and four countries that are not member of the EU but are considered as candidates for enlargement in the future (EUC4); ${ }^{12}$ and the Ukraine to 179 destination countries in 2000-2007), ${ }^{13}$ and for the CIS sample (exports from nine CIS countries including Ukraine $^{14}$ to 179 destination countries in 2000-2007). The time dimension is

\footnotetext{
${ }^{11}$ EU12 includes: Cyprus, Czech Republic, Estonia, Hungary, Latvia, Lithuania, Malta, Poland, Slovakia, and Slovenia that joined EU in 2004; Bulgaria and Romania that joined EU in 2007.

${ }^{12}$ EUC4 includes: Albania, Croatia, Macedonia, and Turkey.

${ }^{13}$ We follow the "in-sample" approach of projecting trade flows because we capture country fixed effects. Therefore, Ukrainian data is used in both the EU and CIS samples. We have also tried the out-of-sample approach and looked at different samples (for example, we included all European countries in the EU sample), but the main conclusions of the paper remained unchanged.

${ }^{14}$ CIS sample includes: Armenia, Azerbaijan, Belarus, Georgia, Kazakhstan, Kyrgyzstan, Moldova, Russia, and Ukraine. Tajikistan, Turkmenistan, and Uzbekistan are not included due to lack of export data.
} 
centered around the 2004 EU enlargement episode. We further predict the Ukrainian exports based on the results for the two different samples and compare them in order to assess the differences in the export patterns.

The main underlying assumption is that if the Ukraine were a part of EU by 2004, its trade patterns were more in line with that of the EU12 members, hence, projecting the trade patterns of the Eastern and Central European countries on the characteristics and geographical location of the Ukraine would provide us with rough estimates of the potential export patterns under the EU integration scenario.

Table 1. Definition of variables and data sources

\begin{tabular}{|c|c|c|}
\hline Variables & Description & Sources \\
\hline \multicolumn{3}{|c|}{ Dependent variables } \\
\hline Export & $\begin{array}{l}\text { Export from i to } \mathrm{j} \text { in sector } \mathrm{k} \text {, in thousands of } \\
\text { curent \$US. COMTRADE exports data } \\
\text { aggregated to two digit SITC } 2 \text { sectors in } \\
\text { 2000-2007 }\end{array}$ & $\begin{array}{l}\text { United Nations } \\
\text { Commodity Trade } \\
\text { Statistics Database }\end{array}$ \\
\hline \multicolumn{3}{|c|}{ Endogenous variables } \\
\hline EU & $\begin{array}{l}\text { EU is an indicator variable that takes value of } \\
1 \text { if country } i \text { was officially announced as a } \\
\text { candidate for the EU accession and takes } \\
\text { value of } 2 \text { if country } i \text { is the EU member, oth- } \\
\text { erwise it takes value of } 0 .\end{array}$ & \\
\hline bothEU & $\begin{array}{l}\text { Binary variable that takes value of } 1 \text { if trading } \\
\text { countries } i \text { and } j \text { are both members of EU and } \\
0 \text { otherwise }\end{array}$ & \\
\hline \multicolumn{3}{|c|}{ Independent variables } \\
\hline $\mathrm{s}$ & $\begin{array}{l}\text { Sector share in total value added. GTAP } \\
\text { sectors are mapped to SITC } 2 \text { sectors }\end{array}$ & $\begin{array}{l}\text { GTAP Input-output } \\
\text { tables }\end{array}$ \\
\hline GDP & Gross domestic product, in current \$US. & $\begin{array}{l}\text { World development } \\
\text { indicators }\end{array}$ \\
\hline Population & Population & $\begin{array}{l}\text { World development } \\
\text { indicators }\end{array}$ \\
\hline Dist & $\begin{array}{l}\text { distance between the biggest cities of coun- } \\
\text { tries } \mathrm{i} \text { and } \mathrm{j} . \mathrm{dkl} \text { is the distance between cities } \\
\mathrm{k} \text { and } \mathrm{l} \text {. (Head and Mayer, 2002) }\end{array}$ & CEPII \\
\hline & $d_{i j}=\sum_{k \in i}\left(\operatorname{pop}_{k} / p o p_{i}\right) \sum_{i \in j}\left(\operatorname{pop}_{l} / \operatorname{pop}_{j}\right) d_{k l}$ & \\
\hline Contig & $\begin{array}{l}\text { Binary variable indicating whether the two } \\
\text { countries are contiguous, } 1 \text { or not, } 0 .\end{array}$ & CEPII \\
\hline
\end{tabular}


Table 1. Definition of variables and data sources (Continued)

\begin{tabular}{|c|c|c|}
\hline Colony & $\begin{array}{l}\text { Binary variable set equal to } 1 \text { if one of the } \\
\text { countries used to be a colony of the other } \\
\text { country. }\end{array}$ & CEPII \\
\hline Same continent & $\begin{array}{l}\text { Binary variable, set equal to } 1 \text { if countries } i \\
\text { and } j \text { located on the same continent. Mapping } \\
\text { of countries to continents was taken from } \\
\text { CEPII geodata. }\end{array}$ & Author's calculations \\
\hline Same religion & $\begin{array}{l}\text { Binary variable set equal to } 1 \text { if countries } i \\
\text { and j share the same religion. Countries are } \\
\text { qualified into one of the six major religions -- } \\
\text { buddhist, catholic, hindu, muslim, orthodox, } \\
\text { protestant -- according to the following rule: } \\
\text { if at least } 50 \text { percent of population in country } \\
\text { i are following one of the major religions } \\
\text { then the country i has major religion, other- } \\
\text { wise the country i is qualified as having no } \\
\text { distinct religion affiliation. Data on religious } \\
\text { composition of population is taken from } \\
\text { CIA- The World Factbook. }\end{array}$ & Author's calculations \\
\hline \multicolumn{3}{|l|}{ Selection variables } \\
\hline Common language & $\begin{array}{l}\text { Binary variable indicating whether countries } \mathrm{i} \\
\text { and } \mathrm{j} \text { share a common language. }\end{array}$ & CEPII \\
\hline Reg. quality & $\begin{array}{l}\text { Regulatory quality index measures the ability } \\
\text { of the government to formulate and imple- } \\
\text { ment sound policies and regulations that per- } \\
\text { mit and promote private sector development } \\
\text { (Kaufmann, Kraay and Mastruzzi, 2007) }\end{array}$ & $\begin{array}{l}\text { Governance matters, } \\
2007\end{array}$ \\
\hline
\end{tabular}

Likewise, projecting the trade patterns of the CIS on Ukraine, would give us rough estimates of the trade patterns of Ukraine under the CIS integration scenario.

\section{A. Dependent Variable}

Table 1 presents the definitions of variables and sources of data. In the empirical analysis, we estimate unidirectional bilateral exports from twelve new EU members (EU12), four EU candidate countries (EUC4), and nine CIS countries to 179 destination countries in 2000-2007 at two-digit level of SITC classification. The export data measured in current US dollars are acquired from the COMTRADE database.

\section{B. Independent Variables}

We differentiate all countries in the sample as non-members, EU candidates, and 
full EU members. A change in the status from a non-member to a candidate is determined according to the announcements made by the European Commission, which are taken from its website. Based on the acquired information, we construct an $\boldsymbol{E} \boldsymbol{U}_{i t}$ variable that indicates the current status of a country with regard to the EU membership. It takes the value of 1 if a country is officially announced as a candidate for accession, 2 if a country is a member of EU, and 0 otherwise. By including this variable, we capture the impact of the change in the EU status on the overall export within a SITC two digit category. During the investigated period two countries were officially announced candidate countries: Croatia in June 2004 and Macedonia in December 2006. All EU12 countries and Turkey have been announced candidates for accession before 2000 while Albania has not received an EU candidate status by 2007. In addition to the $\boldsymbol{E} \boldsymbol{U}_{i t}$ variable, a binary variable $\boldsymbol{b o t h} \boldsymbol{E} \boldsymbol{U}_{i j t}$ is introduced to indicate whether both trading countries are the EU members or not. By including the two variables, we can measure the direct impact of the EU integration on exports within and outside of the EU.

GDP in current US dollars and population data were acquired from the 2008 World Development Indicators (WDI). In addition, we include a set of variables that are routinely used in the gravity models to control for trade costs, geographical location, historical ties, and cultural similarities. Geographical characteristics and distance between countries were collected from the Centre D'Etudes Prospectives et D'Informations Internationales (CEPII) in Paris. Colony and contiguity dummies (whether one of the countries in the country-pair was ever a colony of the other country and whether countries are located on the same continent) were used to control for pair-specific trade costs that are not directly related to distance. Finally, same religion is a binary variable that takes value of 1 if majority of population in both trading countries share the same religion and 0 otherwise to capture the effect of cultural similarities between two nations on trade.

\section{Selection Variables}

For identification of the first stage parameters, we chose two variables that enter the selection equation, but not the gravity equation. The common language dummy controls for the pair-specific fixed costs related to adapting to cultural and linguistic barriers between two countries (translation costs, advertising etc.). To control for country-specific fixed costs related to regulatory quality in exporting and importing countries, we used governance indicators of regulatory quality acquired from the World Bank "Governance matters, 2007" database constructed 
by Kaufmann, Kray, and Mastruzzi (2007). The index of the regulatory quality captures the effectiveness of bureaucracy, amount of red tape, and quality of policies and regulations that encourage free trade. ${ }^{15}$ Exclusion of the variables from the gravity equation can be justified by the fact that the first variable is found as not robust determinant of exports at intensive margin as demonstrated by HMR and Martin and Pham (2008). In addition, we control for cultural differences in the gravity equation by including a common religion dummy. The regulatory quality variable measures effectiveness of government regulations which affects all exporters regardless of the export volume. Finally, since the export decision is estimated at the firm level, we include log GDP per capita in exporting country as a proxy for the factor unit cost parameter.

\section{Results}

This section has the following goals. First, we calibrate the estimation methodology by comparing how the Hausman-Taylor method performs relative to the OLS and fixed effect methods at the aggregate level. Second, we present and discuss the results estimated by the two stage HT procedure at the level of SITC two-digit products. Finally, we calculate export gains form the EU accession of the Ukraine and discuss the main findings.

\section{A. Aggregate Results}

Table 2 reports the estimation results performed by the OLS (columns 1 and 2), first stage selection model (columns 3 and 4), second stage Hausman-Taylor (HT) ${ }^{16}$ (columns 5 and 6), and second stage fixed effect (FE) methods (columns 7 and 8) for the EU and CIS samples. All regressions include exporting- and importingcountry fixed effects, time dummies and a constant term. The country-pair clusterrobust standard errors are presented in parentheses.

Three points are worth mentioning. First, there are important and statistically significant behavioral differences between the two samples regardless of the estimation procedure both for the selection equation and for the gravity model. For the gravity model, exports from the CIS countries are less elastic with respect to

\footnotetext{
${ }^{15}$ Since data on regulatory quality before 2002 are available on a biennial basis, we imputed the missing values for 2001 by using average values between 2000 and 2002 .

${ }^{16}$ Since data on regulatory quality before 2002 are available on a biennial basis, wIn the case of the CIS sample, results of the random effect method are reported because EU and bothEU variables are not included.e imputed the missing values for 2001 by using average values between 2000 and 2002 .
} 
690 Oleksandr Shepotylo

Table 2. Gravity model of aggregate trade flows

\begin{tabular}{|c|c|c|c|c|c|c|c|c|}
\hline & 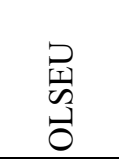 & 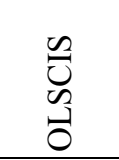 & 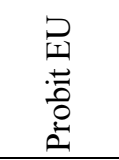 & $\begin{array}{l}0 \\
0 \\
:=0 \\
0 \\
0 \\
0\end{array}$ & 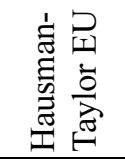 & 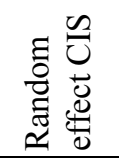 & 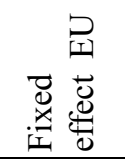 & 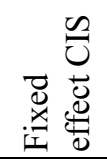 \\
\hline & (1) & (2) & (3) & (4) & (5) & (6) & (7) & (8) \\
\hline \multirow[t]{2}{*}{ Ln(GDPi) } & $0.52^{* *}$ & $0.83^{* *}$ & $0.75^{* *}$ & $0.84^{* *}$ & $0.46^{* *}$ & $0.83^{* *}$ & $0.36^{* *}$ & $0.59^{* *}$ \\
\hline & $(0.137)$ & (0.299) & $(0.025)$ & $(0.035)$ & $(0.095)$ & $(0.195)$ & $(0.096)$ & $(0.205)$ \\
\hline \multirow[t]{2}{*}{$\operatorname{Ln}(\mathrm{GDPj})$} & $0.75^{* *}$ & 0.23 & 0.066 & 0.095 & $0.69^{* *}$ & 0.16 & $0.60^{* *}$ & 0.14 \\
\hline & $(0.078)$ & $(0.185)$ & $(0.098)$ & $(0.106)$ & $(0.058)$ & $(0.133)$ & $(0.056)$ & $(0.134)$ \\
\hline \multirow[t]{2}{*}{ Ln(Dist) } & $-2.40^{* *}$ & $-1.61^{* *}$ & $-1.37^{* *}$ & $-0.90^{* *}$ & $-2.10^{* *}$ & $-1.42^{* *}$ & & \\
\hline & $(0.106)$ & $(0.203)$ & $(0.161)$ & $(0.133)$ & $(0.116)$ & $(0.289)$ & & \\
\hline \multirow[t]{2}{*}{ Contig. Yes $=1$} & $0.42^{* *}$ & $0.63^{*}$ & $-1.36^{* *}$ & $-2.00^{* *}$ & $0.67^{* *}$ & $0.89^{*}$ & & \\
\hline & $(0.162)$ & $(0.248)$ & $(0.420)$ & $(0.467)$ & $(0.189)$ & $(0.395)$ & & \\
\hline \multirow{2}{*}{$\begin{array}{l}\text { Same continent } \\
\text { Yes }=1\end{array}$} & -0.38 & $-0.66^{* *}$ & $-3.47^{* *}$ & -0.058 & -3.25 & $-0.79^{* *}$ & & \\
\hline & $(0.440)$ & $(0.153)$ & $(0.814)$ & $(0.104)$ & $(0.483)$ & $(0.211)$ & & \\
\hline \multirow[t]{2}{*}{ Colony Yes=1 } & 0.044 & $-1.27^{* *}$ & $-1.99^{* *}$ & $-1.99^{* *}$ & 0.33 & -0.39 & & \\
\hline & $(0.286)$ & $(0.362)$ & $(0.406)$ & $(0.630)$ & $(0.242)$ & $(0.621)$ & & \\
\hline \multirow[t]{2}{*}{$\begin{array}{l}\text { Same religion } \\
\text { Yes }=1\end{array}$} & -0.078 & -0.022 & & & -0.073 & 0.18 & & \\
\hline & $(0.078)$ & $(0.179)$ & & & $(0.084)$ & $(0.219)$ & & \\
\hline \multirow[t]{2}{*}{$\begin{array}{l}\text { Common lang. } \\
\text { Yes=1 }\end{array}$} & & & $0.45^{* *}$ & -0.63 & & & & \\
\hline & & & $(0.124)$ & $(0.440)$ & & & & \\
\hline \multirow[t]{2}{*}{ Req. Quality i } & & & $0.57^{* *}$ & $-0.35^{* *}$ & & & & \\
\hline & & & $(0.073)$ & $(0.059)$ & & & & \\
\hline \multirow[t]{2}{*}{ Reg. Quality j } & & & 0.13 & 0.064 & & & & \\
\hline & & & $(0.081)$ & $(0.101)$ & & & & \\
\hline \multirow[t]{2}{*}{$\begin{array}{l}\text { Ln(GDP per } \\
\text { capita i) }\end{array}$} & & & $-0.16^{* *}$ & $-0.67^{* *}$ & & & & \\
\hline & & & $(0.050)$ & $(0.077)$ & & & & \\
\hline \multirow[t]{2}{*}{ EU } & 0.025 & & $0.31^{* *}$ & & 0.025 & & -0.0047 & \\
\hline & $(0.053)$ & & $(0.045)$ & & $(0.036)$ & & $(0.037)$ & \\
\hline \multirow[t]{2}{*}{ bothEU } & 0.062 & & 0.60 & & -0.056 & & -0.072 & \\
\hline & $(0.073)$ & & $(0.331)$ & & $(0.047)$ & & $(0.048)$ & \\
\hline \multirow[t]{2}{*}{$\begin{array}{l}\text { Inverse Mills } \\
\text { ratio, } \eta\end{array}$} & & & & & $1.02^{*}$ & $1.75^{*}$ & $1.69^{* *}$ & 2.15 \\
\hline & & & & & $(0.419)$ & $(0.741)$ & $(0.619)$ & (1.113) \\
\hline \multirow[t]{2}{*}{$\psi$} & & & & & $0.1 .83^{* *}$ & $3.69^{*}$ & 0.57 & 0.33 \\
\hline & & & & & $(0.671)$ & (1.757) & $(0.833)$ & $(2.543)$ \\
\hline \multirow[t]{2}{*}{$\psi^{2}$} & & & & & -0.39 & -0.70 & -0.14 & 0.20 \\
\hline & & & & & $(0.201)$ & $(0.588)$ & $(0.244)$ & $(0.846)$ \\
\hline
\end{tabular}


Table 2. Gravity model of aggregate trade flows (Continued)

\begin{tabular}{|c|c|c|c|c|c|c|c|c|}
\hline$\overline{\psi^{3}}$ & & & & & $\begin{array}{c}0.033 \\
(0.020)\end{array}$ & $\begin{array}{c}0.039 \\
(0.062)\end{array}$ & $\begin{array}{c}0.015 \\
(0.023)\end{array}$ & $\begin{array}{l}-0.048 \\
(0.089)\end{array}$ \\
\hline $\begin{array}{l}\text { Test: } b_{1}=0, b_{2}=0, \\
b_{3}=0, b_{0}=0\end{array}$ & & & & & 62.16 & 51.73 & 7.15 & 3.6 \\
\hline p-value & & & & & 0.000 & 0.000 & 0.000 & 0.006 \\
\hline R-sq overall & 0.80 & 0.73 & 0.478 & 0.520 & & 0.74 & & \\
\hline Observations & 13149 & 5872 & 21366 & 10894 & 13149 & 5872 & 13149 & 5872 \\
\hline \multicolumn{9}{|c|}{$\begin{array}{l}* \mathrm{p}<0.05,{ }^{*} \mathrm{p}<0.01 \\
\text { Note: The dependent variable is log of export from country i to country } \mathrm{j} \text { in models } 1,2,5,6,7 \text {, and } 8 \text {. } \\
\text { The dependent variabe is binary indicator of positive trade in models } 3 \text { and } 4 \text {. The models } 1,3,5 \text {, and } 7 \\
\text { are estimated on sample of EU12 countries, EUC } 4 \text { countries, and Ukraine. The models } 2,4,6 \text {, and } 8 \text { are } \\
\text { estimated for } 9 \text { CIS countries sample, including Ukraine. For models } 3 \text { and } 4 \text { pseudo R-squared is } \\
\text { reported. Cluster robust standard errors are reported in parentheses. Origin and destination country fixed } \\
\text { effects, time dummies, and constant term are included but not reported in all regressions. In model } 5 \text {, } \\
\text { variables EU and both EU are treated as endogenous variables. }\end{array}$} \\
\hline
\end{tabular}

the size of an importing economy and more elastic with respect to the GDP of an exporting country. CIS exports are less elastic in absolute value with respect to the bilateral distance which reflects a higher geographical concentration of trade EU12 within the EU trade area. For the selection equation, better regulatory quality in exporting country and common language increase probability of positive trade flows for the EU sample but have negative effect for the CIS sample. At the same time, lower GDP per capita has much stronger positive effect on the probability of export from the CIS countries.

Second, the change in the status of EU integration does not have a significant effect on the volume of aggregate export but increase probability of positive trade flows for the EU member countries. Third, coefficients of the polynomial approximating $V_{t}^{i j}$ and inverse mills ratio $\eta_{t}^{i j}$ are jointly significant when the two stage procedure is implemented as indicated by the test at the bottom of the table which stresses the importance of including the first stage variables into the gravity equation.

How well the three estimation methods discussed above can predict the geographical pattern of the aggregate export? Panel A of Table 3 shows actual and projected exports from Ukraine to its trading partners in 2000-2007. The first column reports the actual exports. In addition, it reports predictions generated by the OLS, two-stage HT, and two-stage FE methods under three different scenarios: EU1 - Ukraine has been announced an EU accession candidate in 2000, EU2 - in addition to EU1, Ukraine has joined EU in 2004, CIS - Ukraine integrated into CIS 
Table 3. Actual and predicted export of Ukraine in 2000-2007

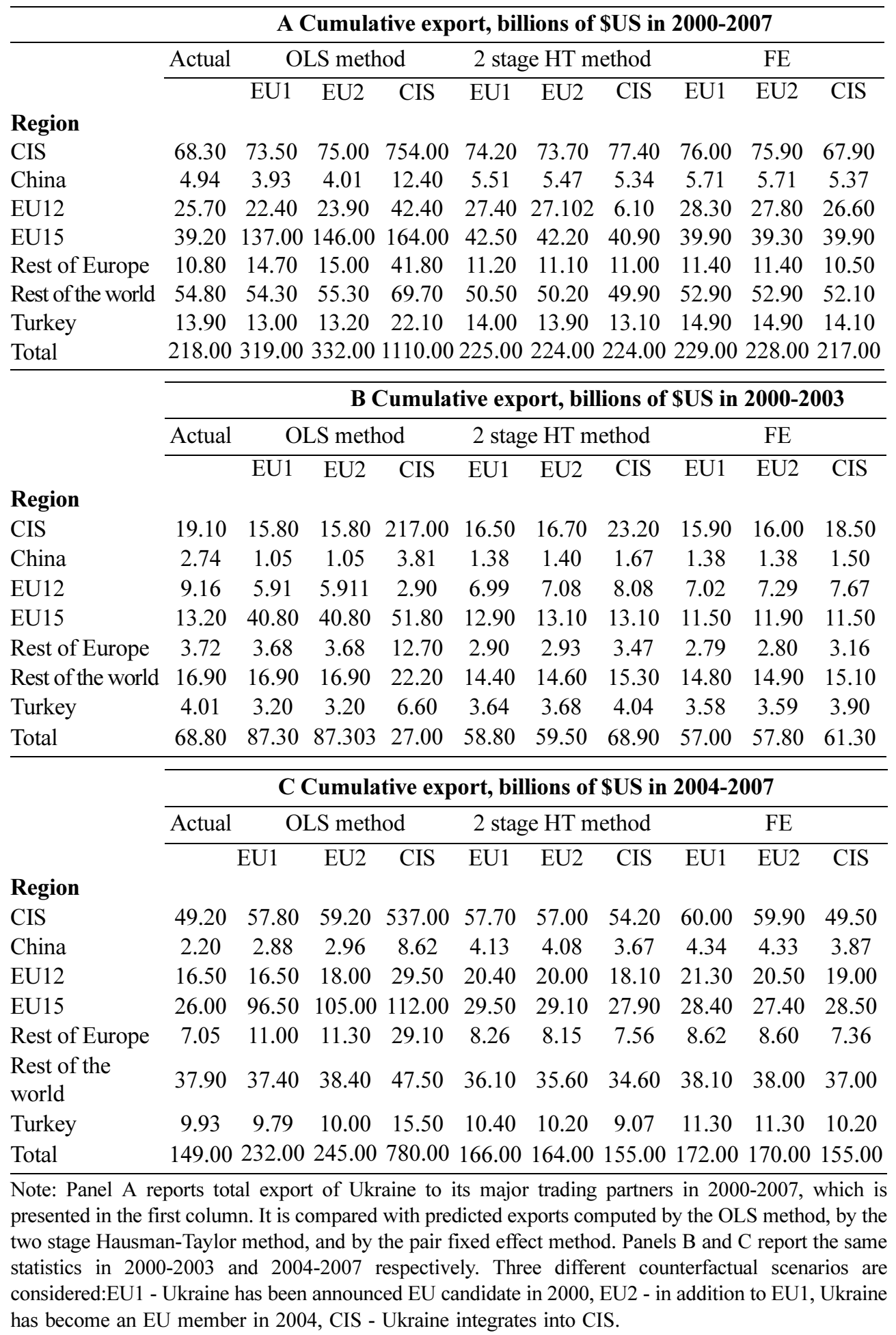


trading bloc. ${ }^{17}$ The OLS method performs poorly in explaining geographical distribution of export. It predicts that deeper CIS integration of Ukraine would increase aggregate export more than four times relative to the actual export. Export to CIS would have increased more than tenfold! It is hard to imagine what would cause such an explosion of trade. Such an implausible result casts substantial doubts on the applicability of the OLS method to predict export flows. The twostage HT and FE methods, on the other hand, generate projections that are in remarkable agreement with each other and with the actual data.

Panel B of Table 3 reports the pre-accession patterns of exports. The HT method predicts that if Ukraine had chosen deeper integration into the CIS bloc, its preaccession export levels would have been very similar to the actual ones, while the deeper EU integration would lead to somewhat lower levels of exports. Under any integration scenario, post-accession exports, reported in the panel C, would have been higher relative to the actual exports. For example, the total export in 20042007 under EU2 would have been 10\% higher than the actual exports. Importantly, the export gains under the EU1 and EU2 scenarios would have been higher relative to the CIS scenario. Predictions generated by the pair fixed effect method show slightly lower export levels before integration and slightly higher export levels after integration relative to the HT method.

Figure 2 reports time series of Ukrainian actual exports as well as predicted exports for EU2 and CIS scenarios to four groups of countries: CIS, EU12, EU15, and the rest of the World. The benefits of the EU integration for the Ukraine would have started playing an important role after 2004 and would accumulate over time. This pattern reflects that integration into EU markets is a long and complex process that does not generates immediate gains, still brings considerable rewards in the long run. ${ }^{18}$

To summarize, the analysis of aggregate trade flows reveals that any integration strategy would be preferable to the current situation of being lost in transition: currently, Ukraine is moving away from CIS but not getting closer to EU. The benefits of the EU integration are higher relative to the CIS integration: by 2007, the deeper EU integration would generate higher export volumes to any trading partner. The change in the accession status would not play an important role for

\footnotetext{
${ }^{17}$ The CIS scenario models Ukraine as a typical CIS country.

${ }^{18}$ The results are not sensitive to the choice of the countries in the sample. As a robustness check, we estimated the model using an enlarged EU sample that in addition included "old" EU members. The results remain the same qualitatively, while there were some minor quantitative changes.
} 
Figure 2. Actual and predicted exports by regions

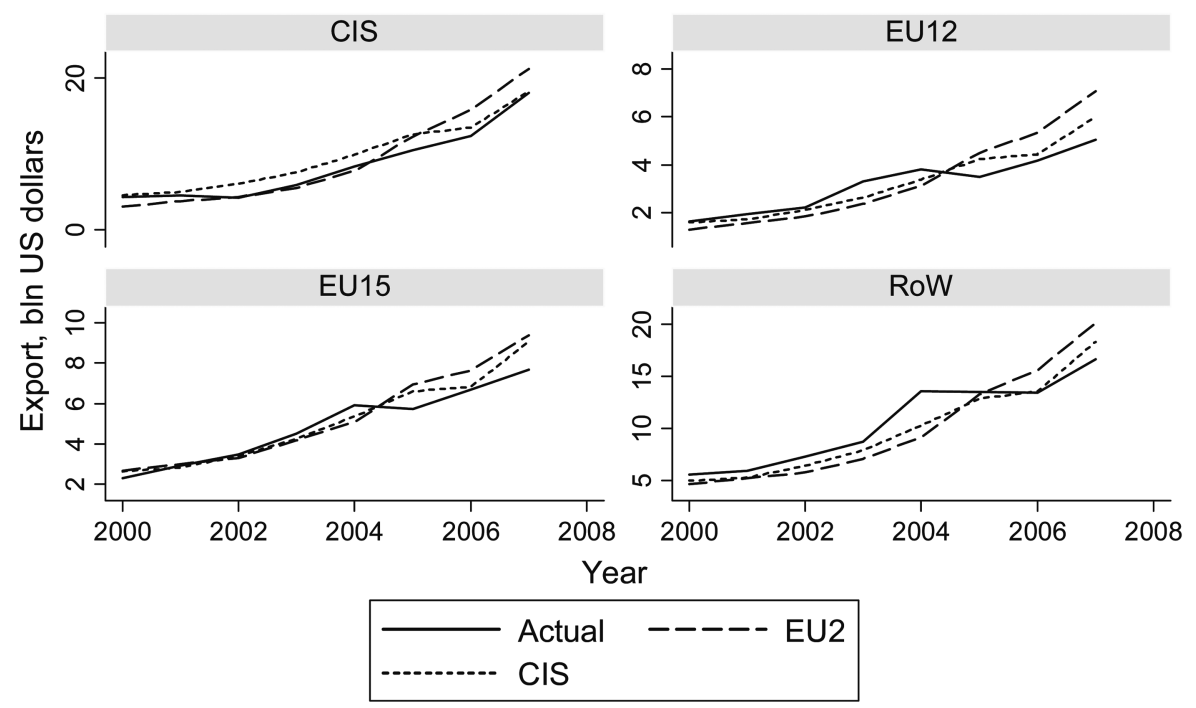

Actual exports compared with two counterfactual scenarios: $1 \mathrm{EU}$ - Ukraine became EU member in 2004, 2 CIS - Ukraine integrated in CISDestination countries are aggregated into four regions: CIS countries of commonwealth of independent states, EU15 - countries that becameEU members before 2004, EU12 - countries that became EU members after 2004, RoW - all other countries

determination of the export levels, while the behavioral change would be the major driving force of export expansion. From the methodological standpoint, taking into account the selection of the trading partners and industry-level heterogeneity are important in generating plausible export predictions: both the two-stage HT and two-stage FE methods are preferable to the one-stage OLS method of estimating the export levels.

\section{B. Forgone Export Gains due to Non-integration at SITC Two-Digit Level}

In this section, we report results of the estimation of the gravity model at SITC two-digit level and estimate forgone export gains in the Ukrainian export under the EU1 and EU2 scenarios against the benchmark CIS scenario. The HT method is preferred over the FE method because it allows controlling for the endogeneity of the EU accession process, while providing results similar to the pair fixed effect method in terms of predicting trade patterns. The industrial structure is captured by an exporting country fixed effect under assumption that composition of industries 
does not change significantly over the investigated period. ${ }^{19}$

Table 4 reports the point estimates of the coefficients of the baseline gravity model estimated by two-stage Hausman-Taylor procedure for 15 selected SITC two-digit products (excluding agriculture, food, and extraction of raw materials) that are the most important exports of Ukraine in 2000-2007. ${ }^{20}$ Unlike on aggregate level, the change in the accession status plays a significant role on exports of some products. Also, there are significant differences of point estimates between EU and CIS samples and across commodity groups. The results for the two-digit commodity groups should be taken with caution because they are less precise and sensitive to the assumptions of the model (Brenton and Di Mauro, 1998). At the same time, the disaggregated model generates predictions that, after aggregating them back to the total export, produce results consistent with the predictions of the

Figure 3. Export gains from Ukrainian EU accession across 2 digit SITC2 products

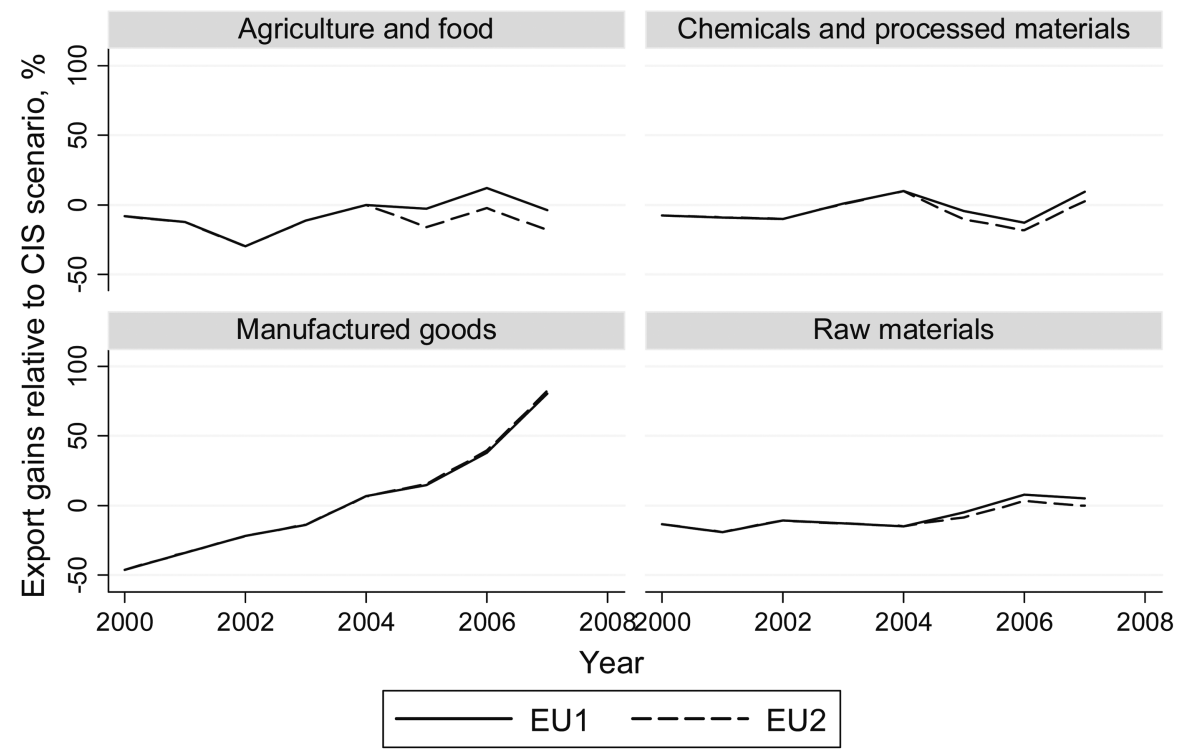

Benchmark CIS scenario is compared with two scenarios of integaration into EU

\footnotetext{
${ }^{19}$ Alternatively, we constructed shares of the value added of each SITC two digit product in the total value added based on Global Trade Analysis Project (GTAP) input-output tables. It does not have a significant impact on our main findings but have two serious drawbacks. For most countries in the sample, the input-output tables are available for only one year. In addition, Moldova and Macedonia are not in the GTAP7 database. Given the drawbacks, this approach reduces the sample size and precludes us from using of exporting counties fixed effects.

${ }^{20}$ Products were rank according to the total value of export in $2000-2007$.
} 
Table 4. Two stage Hausman-Taylor results for selected SITC two-digit industries

\begin{tabular}{|c|c|c|c|c|c|c|c|c|c|c|c|c|c|c|c|}
\hline SIT2 & 51 & 52 & 56 & 64 & 66 & 67 & 68 & 69 & 71 & 72 & 74 & 77 & 78 & 79 & 84 \\
\hline \multicolumn{16}{|c|}{ A. EU sample } \\
\hline \multirow[t]{2}{*}{$\operatorname{Ln}(G D P i)$} & $0.42^{*}$ & -0.41 & 0.31 & $-0.93^{* * *}$ & -0.19 & -0.23 & 0.37 & $0.73^{* * *}$ & $0.62^{* * *}$ & -0.074 & $0.54^{* * *}$ & $0.87^{* * *}$ & $0.81^{* * *}$ & 0.72 & $0.63^{* * *}$ \\
\hline & $(0.211)$ & $(0.448)$ & $(0.741)$ & $(0.205)$ & $(0.164)$ & $(0.204)$ & $(0.284)$ & $(0.163)$ & $(0.187)$ & $(0.171)$ & $(0.142)$ & $(0.160)$ & $(0.188)$ & $(0.387)$ & $(0.179)$ \\
\hline \multirow[t]{2}{*}{$\operatorname{Ln}(G D P j)$} & $0.46^{* * *}$ & $0.36^{* *}$ & 0.25 & $0.50^{* * *}$ & $0.62^{* * * *}$ & $0.96^{* * *}$ & $0.86^{* * *}$ & $0.85^{* * *}$ & $0.60^{* * * *}$ & $0.37^{* * *}$ & $0.47^{* * *}$ & $0.81^{* * *}$ & $0.71^{* * *}$ & -0.33 & $0.97^{* * *}$ \\
\hline & $(0.124)$ & $(0.141)$ & $(0.486)$ & $(0.132)$ & $(0.094)$ & $(0.193)$ & $(0.193)$ & $(0.098)$ & $(0.131)$ & $(0.107)$ & $(0.086)$ & $(0.097)$ & $(0.167)$ & $(0.302)$ & $(0.111)$ \\
\hline \multirow[t]{2}{*}{$\operatorname{Ln}($ Dist $)$} & -0.33 & -2.04 & -1.33 & $-5.94^{* * *}$ & $-1.82^{*}$ & -0.78 & -2.18 & $-2.18^{* * *}$ & -0.20 & $-2.22^{* * *}$ & $-2.33^{* * *}$ & $-1.81^{* * * *}$ & -0.26 & $0.73^{*}$ & $-1.70^{* * *}$ \\
\hline & $(0.548)$ & (1.903) & (1.599) & $(1.545)$ & $(0.794)$ & $(0.813)$ & $(1.567)$ & $(0.357)$ & $(0.924)$ & $(0.411)$ & $(0.343)$ & $(0.361)$ & $(0.965)$ & $(1.102)$ & $(0.324)$ \\
\hline \multirow[t]{2}{*}{ eu } & $0.26^{* *}$ & -0.31 & -0.25 & $-0.74^{* * *}$ & 0.031 & $-0.24^{* *}$ & 0.11 & $0.12^{*}$ & $-0.18^{*}$ & -0.046 & -0.00071 & 0.072 & $0.24^{* *}$ & $0.15-$ & $0.22^{* *}$ \\
\hline & $(0.086)$ & $(0.172)$ & $(0.179)$ & $(0.172)$ & $(0.059)$ & $(0.075)$ & (0.138) & $(0.061)$ & $(0.073)$ & $(0.064)$ & $(0.053)$ & $(0.055)$ & $(0.085)$ & $(0.122)$ & $(0.068)$ \\
\hline \multirow[t]{2}{*}{ bothEU } & -0.012 & $0.28^{*}$ & 0.028 & $0.45^{* * *}$ & 0.20 & $0.49^{* * *}$ & $-0.21-$ & 0.035 & $0.30^{*}$ & $-0.16^{*}$ & -0.0099 & 0.018 & 0.13 & -0.090 & -0.033 \\
\hline & $(0.097)$ & $(0.118)$ & $(0.150)$ & $(0.092)$ & $(0.123)$ & $(0.091)$ & $(0.307)$ & $(0.077)$ & $(0.123)$ & $(0.082)$ & $(0.081)$ & $(0.073)$ & $(0.093)$ & $(0.130)$ & $(0.083)$ \\
\hline \multirow{2}{*}{$\begin{array}{l}\text { Inverse Mills } \\
\text { ratio, } \eta\end{array}$} & 0.78 & 2.10 & 0.84 & $4.10^{* * *}$ & $2.33^{* * *}$ & $1.14^{*}$ & $2.91^{* *}$ & $2.05^{* * *}$ & $1.75^{* *}$ & $1.83^{* * *}$ & $2.50^{* * *}$ & $2.25^{* * *}$ & $2.73^{* * *}$ & 0.0062 & $3.25^{* * *}$ \\
\hline & $(0.471)$ & (1.251) & $(1.075)$ & $(0.764)$ & $(0.477)$ & $(0.511)$ & $(0.975)$ & $(0.255)$ & $(0.576)$ & $(0.272)$ & $(0.250)$ & $(0.271)$ & $(0.556)$ & $(0.802)$ & $(0.280)$ \\
\hline \multirow[t]{2}{*}{$\psi$} & $4.41^{* * *}$ & $6.11^{* *}$ & 3.93 & $2.85^{*}$ & $5.33^{* * *}$ & $6.00^{* * * *}$ & $8.32^{* * *}$ & $3.46^{* * *}$ & $4.51^{* * *}$ & $3.20^{* * * *}$ & $3.54^{* * *}$ & $4.27^{* * *}$ & $8.85^{* * *}$ & $3.81^{*}$ & $8.60^{* * *}$ \\
\hline & (1.128) & (1.948) & $(2.733)$ & (1.243) & $(0.980)$ & $(1.126)$ & (1.591) & $(0.658)$ & (1.153) & $(0.692)$ & $(0.610)$ & $(0.636)$ & $(0.970)$ & $(1.742)$ & $(0.735)$ \\
\hline$\overline{\text { chi }}$ & 22860.1 & 2128.4 & 1123.2 & 3207.9 & 4714.4 & 4476.3 & 2728.7 & 7061.5 & 3700.1 & 5939.6 & 8355.1 & 7972.2 & 5880.0 & 1453.8 & 5952.3 \\
\hline Observations & 7493 & 6691 & 3221 & 9462 & 10154 & 9381 & 6663 & 11778 & 9832 & 9965 & 12034 & 12707 & 9447 & 6576 & 9351 \\
\hline \multicolumn{16}{|c|}{ B. CIS sample } \\
\hline \multirow[t]{2}{*}{$\operatorname{Ln}(G D P i)$} & -0.83 & $3.67^{* * *}$ & -0.65 & 0.38 & -0.014 & -0.29 & $2.06^{* *}$ & 0.27 & 0.12 & -0.47 & -0.44 & -0.09 & $0-0.73$ & $1.38^{*}$ & -0.80 \\
\hline & $(0.774)$ & $(0.472)$ & $(0.751)$ & $(0.594)$ & $(0.435)$ & $(0.529)$ & $(0.704)$ & $(0.398)$ & $(0.443)$ & $(0.351)$ & $(0.335)$ & $(0.342$ & )$(0.392)$ & $(0.649)$ & (0.499) \\
\hline \multirow[t]{2}{*}{$\operatorname{Ln}(G D P j)$} & -0.66 & 0.43 & $-1.00^{* *}$ & $1.33^{* * *}$ & $1.05^{* * *}$ & $1.15^{* * *}$ & 0.56 & $0.82^{* * *}$ & 0.24 & $0.46^{*}$ & $0.34^{*}$ & 0.21 & $0.88^{* * *}$ & $0.76^{* *}$ & $1.81^{* * *}$ \\
\hline & $(0.387)$ & $(0.226)$ & $(0.344)$ & $(0.264)$ & $(0.215)$ & $(0.215)$ & $(0.338)$ & $(0.190)$ & $(0.198)$ & $(0.186)$ & $(0.164)$ & $(0.184)$ & $(0.204)$ & $(0.265)$ & $(0.294)$ \\
\hline \multirow[t]{2}{*}{$\operatorname{Ln}($ Dist $)$} & -1.17 & $-1.41^{*}$ & -0.42 & -1.44 & $-1.79^{* *}$ & -1.10 & $-3.12^{* *}$ & $-2.08^{* * *}$ & -0.46 & -0.67 & $-0.77^{*}$ & $-0.68^{*}$ & -0.045 & $-0.99^{*}$ & $1.80^{*}$ \\
\hline & $(0.752)$ & $(0.590)$ & $(0.964)$ & (1.607) & $(0.575)$ & $(0.835)$ & (1.084) & $(0.479)$ & $(0.415)$ & $(0.460)$ & $(0.367)$ & $(0.334)$ & $(0.459)$ & $(0.443)$ & $(0.831)$ \\
\hline
\end{tabular}


Table 4. Two stage Hausman-Taylor results for selected SITC two-digit industries (Continued)

\begin{tabular}{|c|c|c|c|c|c|c|c|c|c|c|c|c|c|c|c|}
\hline Inverse Mills ratio, $\eta$ & 1.11 & $2.03^{* *}$ & 0.27 & 3.00 & $2.76^{* * *}$ & 0.77 & $5.57^{* * *}$ & $2.77^{* * * *}$ & $2.83^{* * *}$ & $2.73^{* * *}$ & $1.55^{* * *}$ & $2.62^{* * *}$ & $1.78^{* *}$ & $2.51^{* * *}$ & -1.37 \\
\hline$(0.993)$ & $(0.702)$ & $(1.055)$ & $(1.616)$ & $(0.624)$ & $(0.769)$ & $(1.671)$ & $(0.493)$ & $(0.591)$ & $(0.555)$ & $(0.387)$ & $(0.464)$ & $(0.581)$ & $(0.627)$ & $(1.065)$ & \\
\hline$\psi$ & -0.31 & $6.28^{* *}$ & $9.04^{*}$ & $8.65^{* * *}$ & $7.00^{* * *}$ & $4.87^{* *}$ & $7.74^{*}$ & $3.72^{* *}$ & $5.45^{* *}$ & $6.68^{* * *}$ & $3.18^{* *}$ & $5.78^{* * *}$ & $10.0^{* * *}$ & $4.59^{*}$ & $11.2^{* * *}$ \\
\hline$(3.070)$ & $(2.154)$ & $(4.165)$ & $(2.488)$ & $(1.863)$ & $(1.761)$ & $(3.904)$ & $(1.326)$ & (1.749) & $(1.842)$ & (1.183) & $(1.373)$ & $(2.004)$ & $(2.043)$ & $(2.486)$ & \\
\hline Observations & 1753 & 2259 & 1857 & 2629 & 3286 & 3745 & 2305 & 3951 & 3158 & 3342 & 3912 & 4012 & 3197 & 2275 & 2332 \\
\hline
\end{tabular}

Standard errors in parentheses*

$\mathrm{p}<0.05, * * \mathrm{p}<0.01, * * * \mathrm{p}<0.001$

Note: The dependent variable is log of export from country $\mathrm{i}$ to country $\mathrm{j}$ in sektor k. Cluster robust standard errors are reported in parentheses. Origin and destination country fixed effects, time dummies, and constant term are included but not reported in all regressions. Variables EU and both EU are treated as endogenous variables. 
aggregate model. ${ }^{21}$

To evaluate forgone export gains of the EU accession, we generate a dataset with predicted exports of sector $\mathrm{k}$ to region $\mathrm{j}$ at time $\mathrm{t}, T E_{s k t}^{j}$, under the three scenarios: $\mathrm{s}=\{\mathrm{EU} 1, \mathrm{EU} 2, \mathrm{CIS}\}$. The percentage change is calculated according to the following formula: $\Delta_{s k}^{j}=100 \% \frac{T E_{s k}^{j}-T E_{C I S k}^{j}}{T E_{C I S k}^{i}}, s=E U 1, E U 2$.

Figure 3 summarizes how the export gains would evolve over time across four large product groups: agriculture and food, chemicals and processed materials, manufactured goods, and raw materials. ${ }^{22}$ According to the results, by 2007 , Ukraine would have almost doubled export of manufactured goods under the EU2 scenario. This result comes despite the fact that in 2000 the exports of manufactured goods under the EU2 scenario is 50\% lower than under the CIS scenario. Other groups of products does not have such a clear trend but tend to have negative gains at the early stages of the integration process and positive gains at the later stages. Also, the EU2 scenario generates slightly higher gains than the EU1 scenario.

Table 5 presents more disaggregated results for the 15 products to the five groups of countries: CIS, EU12, EU15, RoE (Rest of Europe), RoW (Rest of the world). The highest expected benefits of the Ukraine integrating into the EU would have come from a substantial increase in exports of various types of machinery and equipment (codes 71,72, and 74), road vehicles and transport equipment (codes 78 and 79), and apparel and closing accessories (code 84). These gains would have been virtually uniformly positive across all groups of countries and economically large. As an example, the Ukraine would have increased export of road vehicles (code 78 ) to the CIS countries by $70 \%$ under the EU1 scenario and by $88 \%$ under the EU2 scenario, while export to the EU15 would have been increased by 60 and $82 \%$ respectively.

The export of raw materials, on the other hand, would have either declined as, for example, export of nonferrous metals (code 68) or remained relatively stable as export of iron and steel (code 67). However, the export of manufactures of steel (code 69), one of the most important articles of the Ukrainian export, would have

\footnotetext{
${ }^{21}$ We also estimated the model for the SITC one-digit commodity groups, which generated similar predictions in terms of changes in volume and composition of exports.

${ }^{22}$ Agriculture and food (SITC 1 digit codes 0,1 , and 2), Chemicals and processed materials (codes 5 and 6), Manufactured goods (codes 7 and 8), Raw materials (codes 3 and 4).
} 
Table 5. Export gains from EU integration

\begin{tabular}{|c|c|c|c|c|c|c|c|c|c|c|c|}
\hline & & & & $\mathrm{Re}$ & gion & & & & & & \\
\hline$\overline{\text { SITC2 }}$ & & & IS & $\overline{\mathrm{EL}}$ & $\mathrm{J} 12$ & $\mathrm{EU}$ & $\mathrm{J} 15$ & $\mathrm{R}$ & $\mathrm{oE}$ & & $\mathrm{oW}$ \\
\hline & & $\overline{\mathrm{EU}}$ & EU2 & EU1, & EU2, & EU1, & EU2, & EU1, & EU2, & EU1, & EU2 \\
\hline & & $\%$ & $\%$ & $\%$ & $\%$ & $\%$ & $\%$ & $\%$ & $\%$ & $\%$ & $\%$ \\
\hline 51 & Organic chemicals & 0.4 & 7.9 & -12.0 & -6.0 & -14.0 & -8.9 & 11.3 & 20.2 & -3.4 & 3.2 \\
\hline 52 & Inorganic chemicals & $-10.2-$ & -15.1 & -5.0 & -5.8 & -2.2 & -3.0 & 9.5 & 1.9 & -2.5 & -7.2 \\
\hline 56 & Fertilizers & -9.8 & -13.7 & -6.5 & -10.4 & 9.7 & 6.0 & 15.5 & 9.6 & -10.6 & -13.7 \\
\hline 64 & Paper & -20.9 & -30.5 & -11.9 & -16.0 & 4.0 & -0.7 & -3.4 & -12.3 & 0.4 & -3.4 \\
\hline 66 & Mineral manufactures & -16.4 & -15.8 & -3.4 & 1.9 & -6.3 & -3.4 & -13.4 & -12.8 & -1.2 & -0.8 \\
\hline 67 & Iron and steel & 10.6 & 3.0 & -9.6 & -3.1 & -2.2 & 3.1 & 0.1 & -5.6 & -6.8 & -10.8 \\
\hline 68 & Nonferrous metals & -12.1 & -9.3 & -5.0 & -7.4 & -2.9 & -4.4 & -7.6 & -5.1 & -8.3 & -6.5 \\
\hline 69 & Manufactures of metal & 10.9 & 16.2 & 13.8 & 17.1 & 5.9 & 8.21 & 2.71 & 7.4 & 7.7 & 10.9 \\
\hline 71 & $\begin{array}{l}\text { Power generating } \\
\text { machinery }\end{array}$ & 11.8 & 5.41 & 0.51 & 4.82 & 6.03 & 0.0 & 16.3 & 10.2 & 28.2 & 22.1 \\
\hline 72 & Specialized machinery & 12.3 & 10.6 & 6.1 & -0.4 & 15.4 & 9.7 & 4.6 & 3.1 & 15.3 & 13.8 \\
\hline 74 & General machinery & 16.7 & 16.6 & 21.1 & 20.7 & 26.3 & 26.0 & 19.9 & 19.8 & 16.0 & 16.0 \\
\hline 77 & Electrical machinery & 18.9 & 22.3 & 46.5 & 51.2 & 23.5 & 26.4 & 29.8 & 33.0 & 26.3 & 29.2 \\
\hline 78 & Road vehicles & 70.2 & 88.4 & 37.4 & 59.4 & 60.4 & 81.8 & 52.6 & 67.8 & 21.0 & 29.8 \\
\hline 79 & Transport equipment & -20.7 & -17.3 & -0.3 & 1.32 & 3.12 & 4.91 & 4.61 & 9.73 & 9.6 & 45.0 \\
\hline 84 & Apparel and clothing & 27.3 & 18.9 & 13.9 & 6.2 & 13.7 & 10.2 & 11.3 & 3.6 & -1.1 & -3.4 \\
\hline $\begin{array}{l}\text { Aver- } \\
\text { age }\end{array}$ & & 5.9 & 5.8 & 6.4 & 8.2 & 12.0 & 13.7 & 11.6 & 11.4 & 8.0 & 8.3 \\
\hline
\end{tabular}

Note: Table reports a percentage change in exports of moving from the CIS scenario of integration to the EU1 and EU2 scenarios of integration. The scenarios are EU1 - Ukraine has been announced EU candidate, EU2 - Ukraine has become an EU member in 2004, CIS - Ukraine had deeper integration with CIS. Only 15 most important exports (in terms of total value of actual exports in examined period), excluding agriculture, food, and extraction of raw materials, are reported.

increased uniformly.

The change in the composition of exports towards manufactured products is a positive development for, at least, two reasons. First, experimenting with production of new varieties, a developing country learns its comparative advantage in a competitive environment with high uncertainty about the demand for new products (Hausmann and Rodrik, 2003). As a result, higher share of high quality goods in export is associated with higher future economic growth (Hausmann, Hwang, and Rodrik, 2007). Second, moving away from exporting primary commodities towards exporting manufactured products is desirable because of a general trend towards a decline in terms of trade of primary commodities (Athukurola, 2000). 


\section{Conclusions}

In order to access costs of non-integration of Ukraine in the EU in 2000-2007, we estimate a gravity model at the level of SITC two-digit products applying a newly developed two stage procedure that accounts for selection of exporters and firm-level heterogeneity. We introduce and measure two different channels of the effect of integration on trade: a direct effect of integration and an indirect effect of the behavioral change in the parameters of the gravity equation. Two endogenous variables, $E U_{t}^{i}$ and bothE$U_{t}^{i j}$, capture the former, while differences in the coefficients of the gravity equation estimated for the two different samples capture the latter.

We calibrate the estimation method using the aggregate data and show that the two-stage HT and two-stage pair-fixed effect methods generate similar predictions, while a simple OLS method produce highly implausible results. Any integration strategy would be preferable to the current situation of inaction. Yet, the benefits of the EU integration are higher relative to the CIS integration. Therefore, the vector of integration into EU should be supported by Ukrainian policymakers as a better integration strategy.

Moving to the disaggregated data, we estimate the costs of non-integration into the EU bloc relative to the integration into the CIS bloc at the level of SITC twodigit products and find that the most losses in terms of foregone exports are expected in manufactured goods with almost doubled exports in 2007 relative to the CIS scenario. There are several important directions for future work. The paper looks at the impact of the EU integration on exports, while integration can have important effects on imports, labor market, foreign direct investments, and economic growth. Also the paper did not discuss the supply side of membership. It simply assumes that Ukraine could join at some point if it is beneficial for the country. However, an important question is: would it be beneficial for the EU to integrate Ukraine? To answer this question requires an analysis of costs and benefits of Ukrainian accessions for the current EU members.

\section{Acknowledgements}

The author thanks the anonymous referee, Tom Coupe, Randall Filer, David Tarr, participants at the GDN 2010 conference in Prague, ETSG 2009 conference in Rome, and University of Houston seminar for their helpful suggestions and 
comments.

Received 21 January 2010, Revised 21 July 2010, Accepted 4 August 2010

\section{References}

Anderson, J., \& E. van Wincoop (2003), Gravity with Gravitas: A Solution to the Border Puzzle. American Economic Review, 93(1), pp. 170-192.

Athukurola, P.C. (2000), Manufacturing exports and terms of trade of developing countries: Evidence from Sri Lanka. Journal of Development Studies, 36, pp. 89-104.

Baier, S., \& J. Bergstrand (2004), Economic Determinants of Free Trade Agreements. Journal of International Economics, 64(1), pp. 29-63.

Baldwin, R., \& D. Taglioni (2006), Gravity for Dummies and Dummies for Gravity Equations. NBER Working Papers: 12516.

Baldwin, R. (2006), Multilateralising Regionalism: Spaghetti Bowls as Building Blocs on the Path to Global Free Trade. World Economy, 29(11), pp. 1451-1518.

Baldwin, R. (1995), The Eastern Enlargement of the European Union. European Economic Review, 39(3-4), pp. 474-481.

Baldwin, R. (1994), Towards an integrated Europe. London: Center for Economic Policy Research.

Baldwin, R. (1993), A Domino Theory of Regionalism, NBER Working Paper 4465 (Cambridge). Published as: Baldwin, R. E. (1995), The Domino Theory of Regionalism, in R. E. Baldwin, P. Haaparanta and K. Kiander (eds.), Expanding Membership of the European Union, Cambridge: Cambridge University Press.

Beckmann, E. and J. Fidrmuc (2009), Oil Price Shock and Structural Changes in CMEA Trade, Discussion Papers in Economics 10963, University of Munich, Department of Economics.

Bernard, Andrew B., Eaton, J, Jensen, JB, and S Kortum. (2003), Plants and Productivity in International Trade. American Economic Review, 93(4), pp. 1268-1290.

Brenton, P. and F. Di Mauro (1998), Is there Any Potential in Trade in Sensitive Industrial Products Between the CEECs and the EU?, World Economy, 21, pp. 285-304.

Bussiere, M., Fidrmuc, J., \& B. Schnatz (2008), EU Enlargement and Trade Integration: Lessons from a Gravity Model. Review of Development Economics, 12(3), pp. 562576.

Egger, P., Pfaffermayr, M., \& R. Schmidt (2007), Trade in Western and Eastern Europe in the Aftermath of COMECON: An Assessment of Behavioral Change. Oxford Economic Papers, 59(1), pp. 102-126.

Gros, D., \& A. Gonciarz (1996), A Note on the Trade Potential of Central and Eastern Europe. European Journal of Political Economy, 12(4), pp. 709-721.

Havrylyshyn, O. and L. Pritchett (1991), European trade patterns after the transition. Policy Research Working Paper Series 748, The World Bank. 
Hamilton, C., \& L. Winters (1992), Opening Up International Trade with Eastern Europe. Economic Policy: A European Forum, 14, pp. 77.

Hausman, J., \& W. Taylor (1981), Panel Data and Unobservable Individual Effects. Econometrica, 49(6), pp. 1377-1398.

Hausmann, R., Hwang, J., \& D. Rodrik (2007), What You Export Matters. Journal of Economic Growth, 12(1), pp. 1-25.

Hausmann, R., \& D. Rodrik (2003), Economic Development as Self-Discovery. Journal of Development Economics, 72(2), pp. 603-633.

Helpman, E., Melitz, M., \& Y. Rubinstein (2008), Estimating Trade Flows: Trading Partners and Trading Volumes, Quarterly Journal of Economics, 123(2), pp. 441487.

Kaufmann, D., Kraay, A., \& M. Mastruzzi (2007), Governance Matters VI: Governance Indicators for 1996-2006. World Bank Policy Research Working Paper No. 4280, Available at SSRN: http://ssrn.com/abstract $=999979$.

Nilsson, L. (2000), Trade Integration and the EU Economic Membership Criteria, European Journal of Political Economy, 16(4), pp. 807-827.

Martin, W., \& C. Pham (2008), Estimating the Gravity Equation when Zero Trade Flows are Frequent, Unpublished manuscript.

McPherson, M., \& W. Trumbull (2008), Rescuing Observed Fixed Effects: Using the Hausman-Taylor Method for Out-of-Sample Trade Projections. International Trade Journal, 22(3), pp. 315-340.

Melitz, M. (2003), The Impact of Trade on Intra-industry Reallocations and Aggregate Industry Productivity. Econometrica, 71(6), pp. 1695-1725.

Mitra, P. (2008), Innovation, Inclusion and Integration: From Transition to Convergence in Eastern Europe and the Former Soviet Union. Washington, D.C.: The World Bank.

Pelzman, J. (1977), Trade Creation and Trade Diversion in the Council of Mutual Economic Assistance: 1954-70. American Economic Review, 67(4), pp. 713-722.

Serlenga, L., \& Y. Shin (2007), Gravity Models of Intra-EU Trade: Application of the CCEP-HT Estimation in Heterogeneous Panels with Unobserved Common TimeSpecific Factors. Journal of Applied Econometrics, 22(2), pp. 361-381.

Wang, Z., \& L. Winters (1991), The Trading Potential of Eastern Europe. CEPR Discussion Paper no. 610. London, Centre for Economic Policy Research, http:// www.cepr.org/pubs/dps/DP610.asp.

World Bank (2005), From Desintegration to Reintegration: Eastern Europe and the Former Soviet Union in International Trade. Edited by H. Broadman. 